\title{
Friction and Wear Behavior of Ti-6Al-7Nb Biomaterial Alloy
}

\author{
Mamoun Fellah $^{1 *}$, Omar Assala ${ }^{1}$, Mohamed Labaïz ${ }^{1}$, Leila Dekhil ${ }^{2}$, Alain Iost $^{3}$ \\ ${ }^{1}$ Surface Engineering and Tribology Team, Laboratory of Metallurgy and Engineering Materials, BADJI Mokhtar-Annaba University, \\ Annaba, Algeria; ${ }^{2}$ Laboratory of Formability and Metallic Materials, BADJI Mokhtar-Annaba University, Annaba, Algeria; ${ }^{3}$ La- \\ boratory of Metallurgy, ARTS ET METIERS ParisTech, Lille, France. \\ Email: *mamoun.fellah@yahoo.fr, asslo23@gmail.com,m.labaiz@univ-annaba.org, dekhil23@yahoo.fr, Alain.iost@ensam.eu
}

Received 28 January 2013; revised 1 March 2013; accepted 1 April 2013

Copyright (C) 2013 Mamoun Fellah et al. This is an open access article distributed under the Creative Commons Attribution License, which permits unrestricted use, distribution, and reproduction in any medium, provided the original work is properly cited.

\begin{abstract}
Titanium has been increasingly applied to biomedical application because of its improved mechanical characteristics, corrosion resistance and biocompatibility. However their application remains limited, due to the low strength and poor wear resistance of unalloyed titanium. The purpose of this study is to evaluate the friction and wear behavior of high-strength titanium alloys: Ti-6Al-7Nb used in femoral stem (total hip prosthesis). The oscillating friction and wear tests have been carried out in ambient air with oscillating tribotester in accord with standards ISO 7148, ASTM G99-95a, ASTM G 133-95 under different conditions of normal applied load $(3,6$ and $10 \mathrm{~N})$ and sliding speed $(1,15$ and $25 \mathrm{~mm} \cdot \mathrm{s}^{-1}$ ), and as a counter pair we used the ball of $100 \mathrm{C} 6,10 \mathrm{~mm}$ of diameter. The surface morphology of the titanium alloys has been characterized by SEM, EDAX, micro hardness, roughness analysis measurements. The behavior observed for both samples suggests that the wear and friction mechanism during the test is the same for Ti alloys, and to increase resistance to wear and friction of biomedical titanium alloys used in total hip prosthesis (femoral stems) the surface coating and treatment are required.
\end{abstract}

Keywords: Tribological Behavior; Friction and Wear Tests; Biomaterial; Total Hip Prosthesis; Ti-6Al-7Nb

\section{Introduction}

Titanium and its alloys have been used as implant materials due to their very good mechanical and corrosion resistance and biocompatibility [1-7]. The most used biomaterials were commercially pure titanium (CP-Ti) which is used in clinics $[8,9]$, although CP-Ti has been pointed out to have disadvantages of low strength, difficulty in polishing, and poor wear resistance [10]. Therefore, Titanium is still insufficient for high-stress applications; e.g., long spanned fixed prostheses and the frameworks of removable partial dentures $[11,12]$.

Ti-6Al-4V alloy, originally developed as an aeronautical material, has been tested as a replacement for CP-Ti, because of its high mechanical properties with sufficient corrosion resistance [13-17]; however, the cytoxicity of elemental Vanadium is questionable [18-20]. Subsequently, some researches prove that Vanadium and Aluminum ions released from this ternary alloy can induce cytotoxic effects or neurological disorders, respectively

${ }^{*}$ Corresponding author.
$[21,22]$. Also, for long-term, this alloy has transferred in sufficient load to adjacent bones, resulting in bone resorption and eventual loosening of the implant $[23,24]$.

Another ternary alloy used as implants was Vanadium free, $\alpha+\beta$ alloy, especially Ti-6Al-7Nb alloy [25-27] that revealed improved mechanical characteristics, corrosion resistance and biocompatibility. Developed for orthopedics application as a wrought material, it has been evaluated as a new alloy for total hip prostheses. Niobium exhibits a similar effect to Vanadium in stabilizing $\beta$ phase in the Ti-Nb binary system, which is necessary for providing the $\alpha, \beta$ two-phase structure. Therefore, Niobium was used as the ternary element to produce the desirable microstructure in the Ti-6Al-7Nb alloy [28].

As compared with Ti-6Al-4V alloy, in a tensile test, these alloys show slightly lower strength and about $40 \%$ higher elongation. In addition, after long term immersion in $1.0 \%$ lactic acid, the amount of Titanium ion released from $\mathrm{Ti}-6 \mathrm{Al}-7 \mathrm{Nb}$ alloy was less than that from Ti-6Al$4 \mathrm{~V}$ alloy and comparable to that from titanium [29]. Ti-6Al-7Nb alloy showed castability slightly lower than 
that of CP-Ti, but less casting porosity, which is advantageous in terms of reliability of castings [29].

Although Ti-6Al-7 $\mathrm{Nb}$ alloy castings have been investigated for orthopedics application from several aspects such as mechanical properties, corrosion resistance and castability, no studies have reported on friction and wear resistance, which is an important factor for a material for total hip prostheses. In this study, friction and wear characteristics of Ti-6Al-7 $\mathrm{Nb}$ alloys were evaluated by a ball on disc tribometre in accord with standards ISO 7148, ASTM G99-95a, ASTM G 133-95.

\section{Materials and Methods}

\subsection{Materials}

The materials used in this study are the Ti-6Al-7Nb as a total hip prosthesis (femoral stem) and Ti-6Al-4V that was cuted from a titanium cylindrical bar correspond to ISO 5832-3 part 3/01-07-199 (was supplied by ENSAM Lille, France). The composition of titanium alloys used in this study is specified in Table 1. It is known that the fixation of the implant is greatly dependent on good mechanical interlocking between the rough surface of the implant and tissue [30]. So, the surfaces of the alloys were abraded with 600 abrasive papers firstly and polished with colloidal silica, all the samples were cleaned in an ultrasonic bath with acetone, ethanol, and distilled water, respectively, for $10 \mathrm{~min}$ and then dried in hot air and saved in the desiccators for use in different characterizations.

\subsection{Tribological Study}

Pin on disc, ball on disc and sphere on plan tribological tests (Figures 1 and 2) were carried out using the following prosthetic materials: Ti-6Al-4V and Ti-6Al-7Nb alloys, against $100 \mathrm{C} 6$ and abrasive paper number 320 (Sic).

\subsubsection{Plan Contact}

The contact pair, which studies the tribological pair, is, in this case, the sample Ti-6Al-7Nb and sandpaper (320 abrasive papers). The parameters taken into account for this test are the applied load and the rotational speed. The test time is kept constant, and the weight loss is the difference in weight of the sample weighed before and after the test with a microelectronic balance whose accuracy is of the order $10^{-3} \mathrm{~g}$. The samples were cleaned with acetone before each weight; the surface roughness of the test sample is measured before and after the test.

\subsubsection{Friction Behavior}

In this work, friction and wear tests have been carried out, in ambient air with oscillating tribometer in accord with standards ISO 7148, ASTM G99-95a, ASTM G 133-95

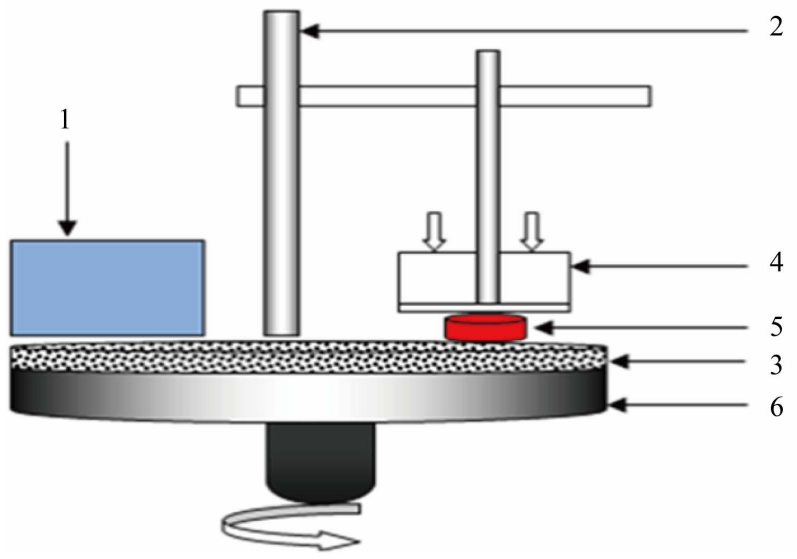

Figure 1. Scheme of the contact geometry (plan contact): 1: speed regulator, 2: support, 3: rotating tray, 4: load applied, 5: sample, 6: retaining frame. Friction pair used: Ti-6Al$7 \mathrm{Nb}$ sliding against number 320 abrasive paper. Sliding distance: $1400 \mathrm{~m}$.

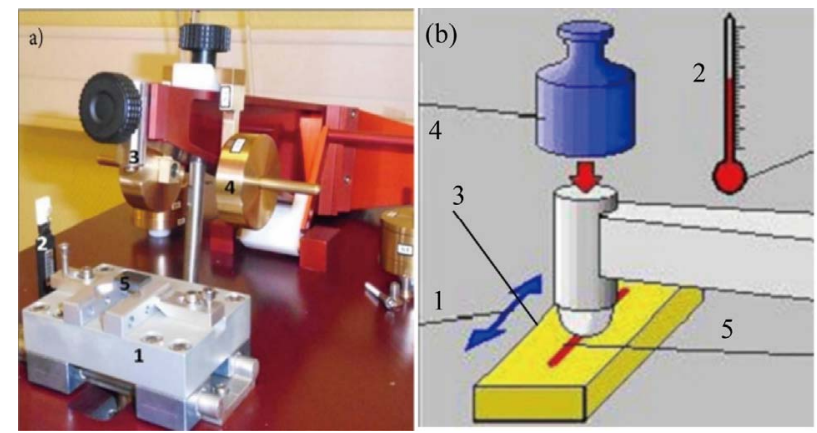

Figure 2. (a) Photography and (b) Scheme of the contact geometry (alternative movement) and Tribotester System: 1: table, carry sample on alternative movement (wear track radius $=10 \mathrm{~mm}$ ), 2: a sensor to measure heat and humidity, 3: ball 100C6 steel, 4: load applied FN, 5: Sample.

(Figure 2), under different condition of normal load (3, 6 and $10 \mathrm{~N}$ ) and sliding speed $\left(1,15\right.$ and $\left.25 \mathrm{~mm} \cdot \mathrm{s}^{-1}\right)$, as a counter pair we used the $100 \mathrm{C} 6$ ball, $10 \mathrm{~mm}$ in diameter as presented in Table $\mathbf{2}$.

\section{Results and Discussion}

\subsection{Surface and Microstructural Analysis Microstructure}

1) An acidic etchant $\left(3 \mathrm{ml} \mathrm{HF}, 6 \mathrm{ml} \mathrm{HNO}{ }_{3}\right.$ and $100 \mathrm{ml}$ $\mathrm{H}_{2} \mathrm{O}$ for $10 \mathrm{~s}$ to reduce the influence of surface hardening.

2) The samples are mechanically polished and chemi-

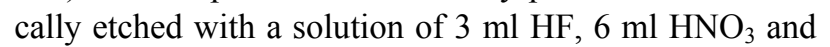
$100 \mathrm{ml} \mathrm{H}_{2} \mathrm{O}$ for $10 \mathrm{~s}$ to reduce the influence of surface hardening, the microstructure was studied using optical microscopy (Leica DMLM).

3) The microstructure of Titanium alloy was shown in Figure 3 respectively, the photography consisted of glo- 
Table 1. Chemical composition (wt\%) of Ti-6Al-7Nb.

\begin{tabular}{cccccccccccc}
\hline Element & $\mathbf{A l}$ & $\mathbf{N b}$ & $\mathbf{V}$ & $\mathbf{F e}$ & $\mathbf{M o}$ & $\mathbf{O}$ & $\mathbf{S i}$ & $\mathbf{C}$ & $\mathbf{T a}$ & $\mathbf{N}$ & $\mathbf{T i}$ \\
\hline $\mathbf{\%}$ & 6.2 & 7.4 & - & 0.10 & 0.005 & 0.0001 & 0.0002 & 0.0015 & 0.46 & - & Balance \\
\hline
\end{tabular}

Table 2. Work condition of the alternative movement wear test oscillating tribotester.

\begin{tabular}{cc}
\hline Friction pairs used & $\begin{array}{c}\text { 1) Ball } 1006 \mathrm{C} / \mathrm{Ti} 6 \mathrm{Al} 4 \mathrm{~V}, \\
\text { 2) Ball } 1006 \mathrm{C} / \mathrm{Ti} 6 \mathrm{Al} 7 \mathrm{Nb}\end{array}$ \\
\hline Sliding speed & 1,15 and $25 \mathrm{~mm} \cdot \mathrm{s}^{-1}$ \\
Normal load & 3,6 and $10 \mathrm{~N}$ \\
Wear track radius & $10 \mathrm{~mm}$ \\
100C6 ball diameter & $10 \mathrm{~mm}$ \\
Temperature & $25^{\circ} \mathrm{C}$ \\
Humidity & $38 \%$ \\
\hline
\end{tabular}

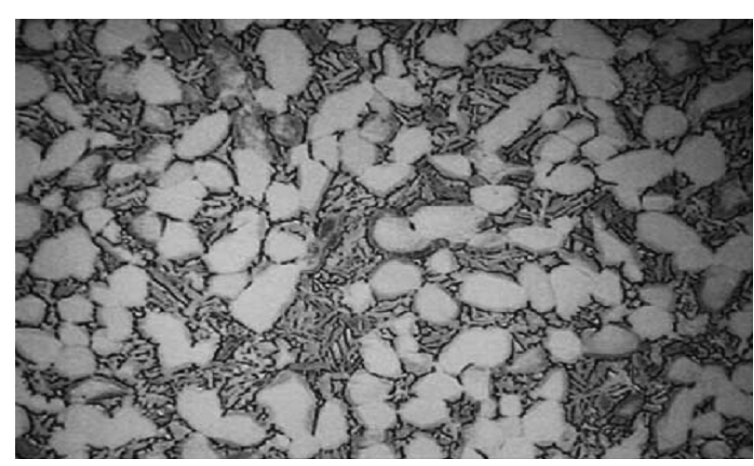

Figure 3. Optical micrographs showing the microstructure of Ti-6Al-7Nb alloy etched with a solution of $3 \mathrm{ml} \mathrm{HF}, 6 \mathrm{ml}$ $\mathrm{HNO}_{3}$ and $100 \mathrm{ml} \mathrm{H}_{2} \mathrm{O}$ for $10 \mathrm{~s}$ the figure consisted of globular and acicular $\alpha$ grains (white grains) within a matrix containing equiaxial grains $\beta$ (dark grains).

bular and acicular $\alpha$ grains (white grains) within a matrix containing equiaxial grains $\beta$ (dark grains). The acicular shape of the $\alpha$ phase is present in the Figure 3 in an arrangement known as basket-weave which characterizes the Widmanstätten structure.

4) The chemical composition presented in Table $\mathbf{1}$ was acquired using spectrometer (Spectrolab) and energydispersive spectroscopy (EDS, PHILIPS XL 30 ESEMFEG, and EDX IMIX-PTS.

5) The titanium samples were examined using energy dispersive X-Ray (EDX) analysis. The spectra for the overall analysis are shown in Figures 4 and 5. The EDX spectrum shows different peaks that correspond to the different elements contained in the substrate. In the case of Ti-6Al-7Nb, the Ti peak is more pronounced than that of aluminum ( $\mathrm{Al})$, Niobium $(\mathrm{Nb})$, iron $(\mathrm{Fe})$, Molybdenum (Mo) and tantalum (Ta) are also present. The chemical compositions of the studied samples were in compliance with that of a Ti-6Al-7 Nb. The instrumented microharndnesse (Figures 6 and 7), was studied using ZWICK 2.5.

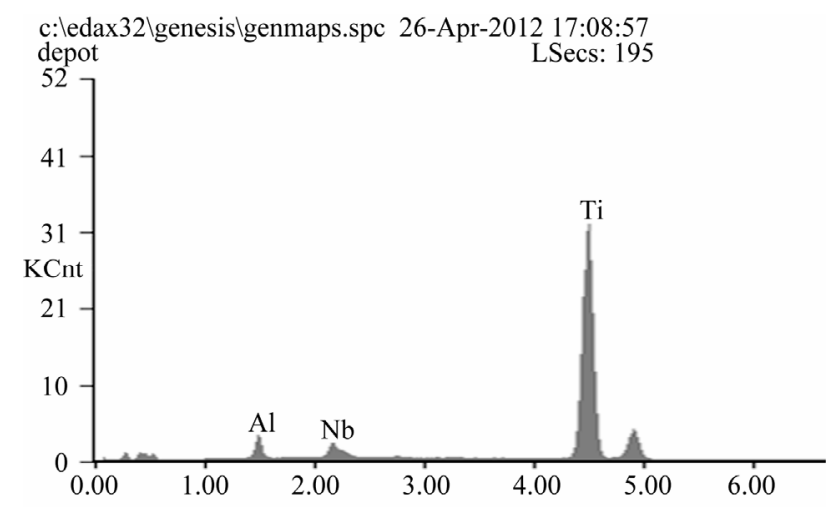

Figure 4. EDAX microanalysis of Ti-6Al-7Nb alloy.

The roughness (Figure 8) of the samples in 3D was studied using Surface Data Veeco: Mag 5.0 X, Mode VSI.

\section{Roughness Analysis}

The studied substrates are of biomedical interest. They must therefore meet the standards imposed by the field of biomedicine particularly at the surface of the material deposited on the auricular surfaces of hip prostheses in which Ti-6Al-4V and Ti-6Al-7Nb are the hip implant. The roughness of the samples was obtained (Table 3 and Figures 8(a)-(c)), meets the standards of biomedicine, namely, roughness for metal parts as specified in ISO 7206-2:1996 [32]. The roughness values samples were 5.03 and $0.01 \mu \mathrm{m}$ for Ti-6Al-7Nb before and after polishing respectively and $0.06 \mu \mathrm{m}$ for Ti-6Al-4V after polishing.

\subsection{Tribological Study}

\subsubsection{Plan Contact}

The weight loss (Figure 9) of titanium samples, tested at $3.5 \mathrm{~N}$ loads, is approximately proportional to the number of revolutions. Nevertheless, the wear was systematically greater to Ti-6Al-7 $\mathrm{Nb}$ as expected. The behavior observed for both samples suggests that the wear mechanism during the test is the same (abrasive wear). In the case of Ti-6Al-4V samples, its weight loss was $\sim 85 \%$ of the one observed for the Ti-6Al-7Nb samples. According to the Archard's law, the volumetric loss of the material is inversely proportional to the hardness value of the material [33]. This implies that the higher the hardness of the material, the smaller is the volume loss. The present alloys exhibit significant difference in hardness values, so that the experimental sliding wear data correlate well 


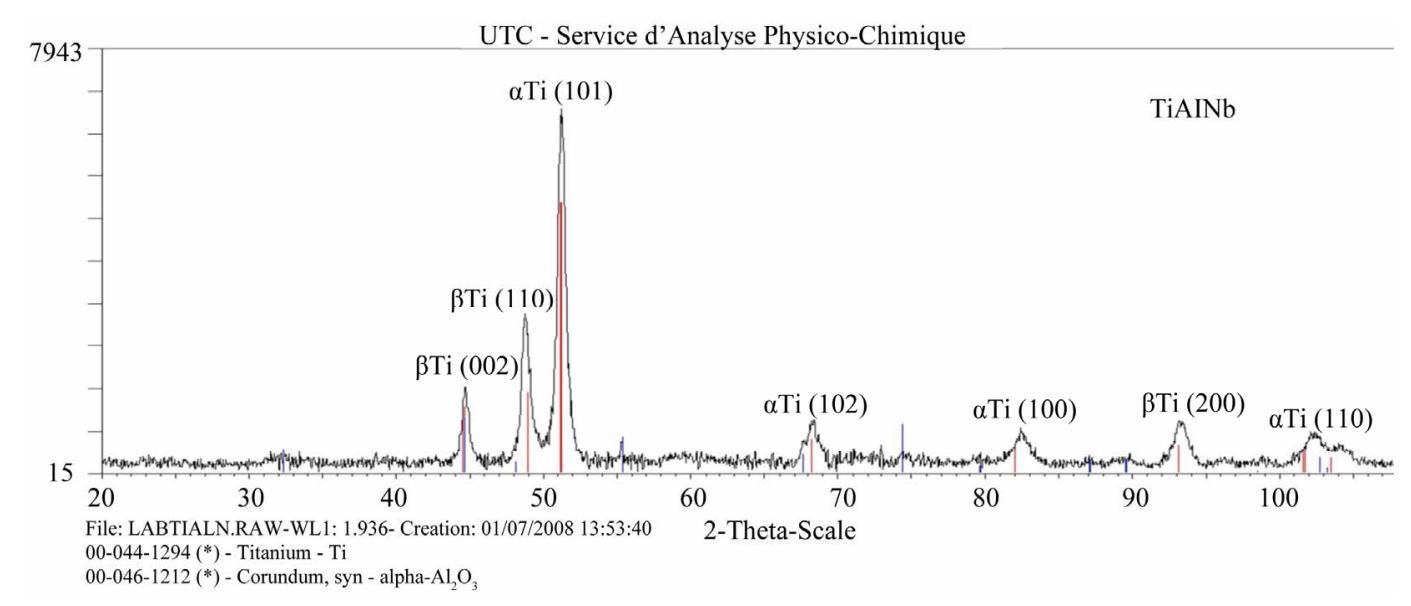

Figure 5. XRD patterns of Ti-6Al-7Nb alloy.

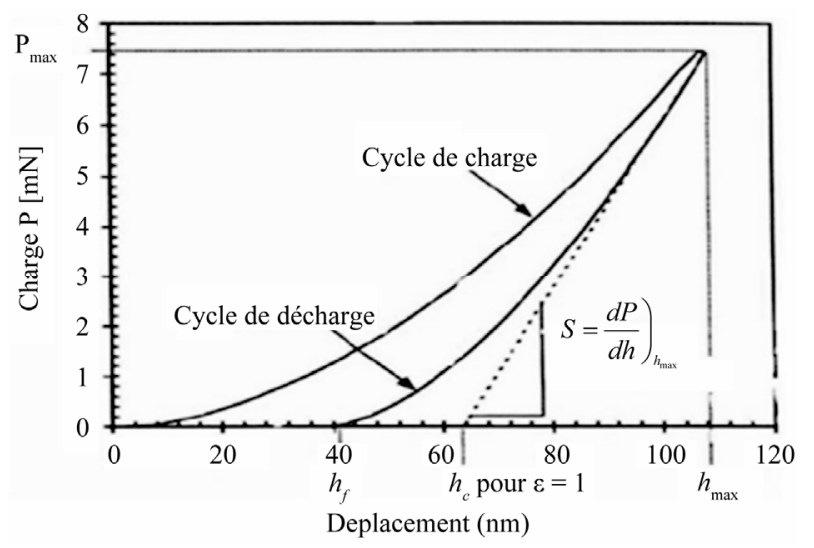

Figure 6. Example of micro-hardness P-h curve [31].

with Archard's law.

\subsubsection{Friction Coefficient}

It is instead to know the wear and friction coefficient of ball 100C6 steel (Figure 10), before studying the coefficient of friction of samples.

The evolution curves of friction coefficient of $\mathrm{Ti} 6 \mathrm{~A} 7 \mathrm{Nb}$ versus sliding distance (number of cycles) Table 4 and Figures 11-18 are almost the same form wholes in terms of load and speed. The analysis of these curves to distinguish several periods, or successive regimes of friction and wear:

1) The first period, during which the friction coefficient increases rapidly, an accommodation, is the surface of the first body the most ductile [34], in this case the steel. The relief is so attenuated; the roughness of the surface of the steel is reduced by plastic deformation

2) The second period is characterized by a slight decrease in the friction coefficient. Probably, the third body on the track generated by frictional wear of the steel plays a role comparable to that of a solid lubricant.

3) The third period is defined by a significant increase in the friction coefficient. The third body is fragmented

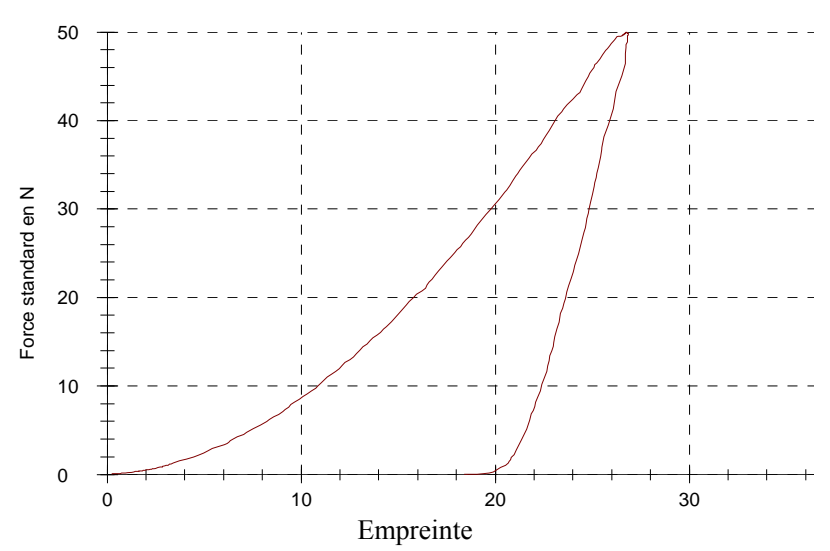

(a)

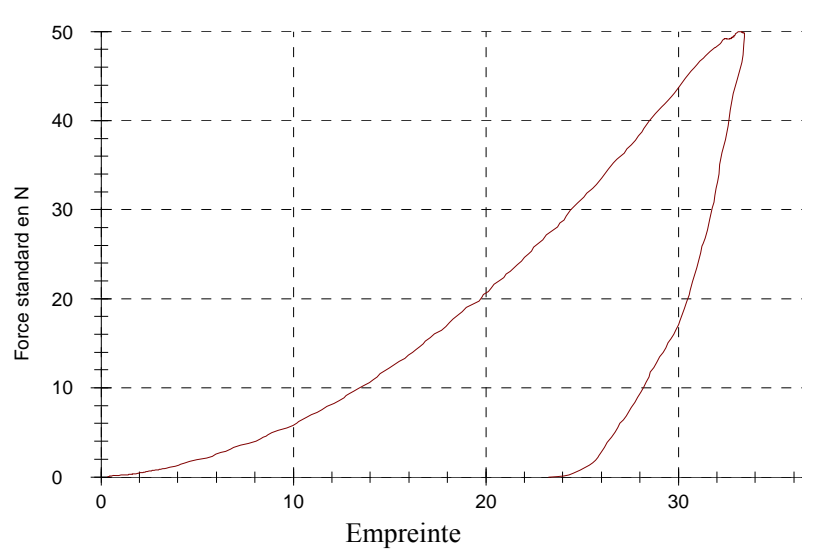

(b)

Figure 7. $\mathbf{P}-\mathbf{h}$ curves during micro hardness experiments with loading speed $\left(0.2 \mathrm{~mm} \cdot \mathrm{min}^{-1}\right)$, under a maximum load $(50 \mathrm{~N})$ of: (a) Ti-6Al-4V; (b) Ti-6Al-7Nb.

and oxidizes very probably plays a role abrasive, then the virtual stabilization of the friction coefficient.

4) The fourth and final period is near stabilization of the friction coefficient.

The friction test results of Ti-6Al-7Nb and Ti-6Al-4V, are illustrated in Table 4 and Figures 11-18 respectively. 
(a)

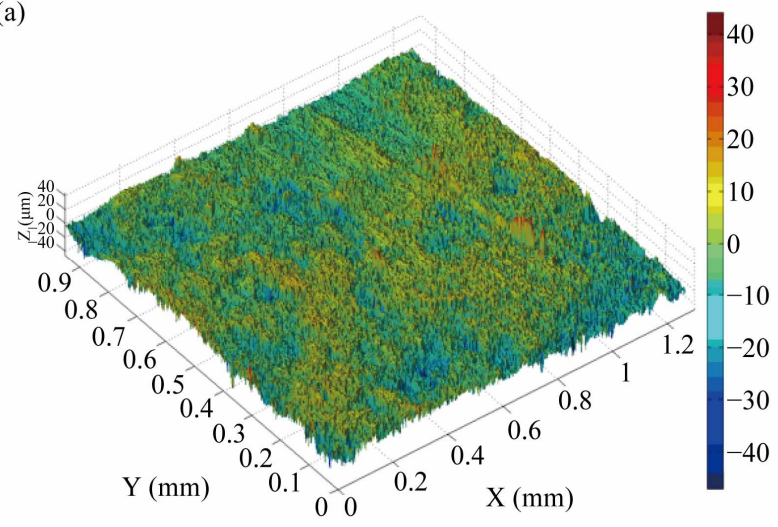

(b)
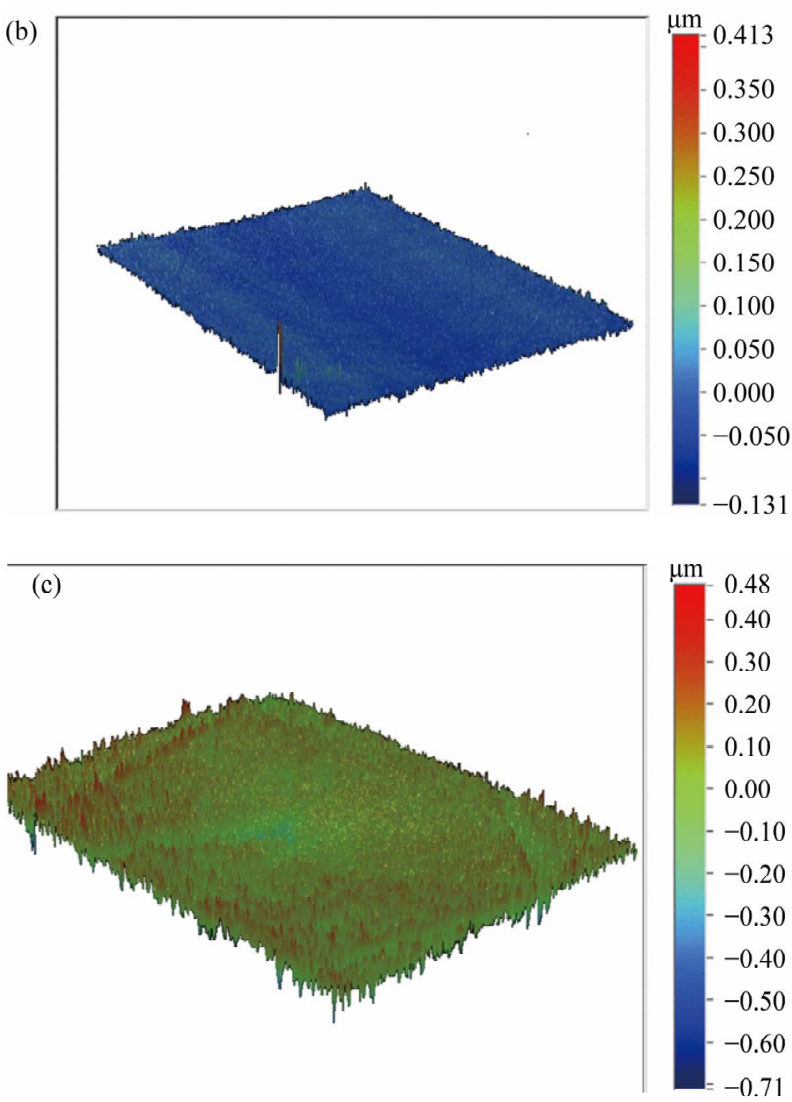

Figure 8. The optical 3D photo of Ti alloys, (a) Ti-6Al-7Nb before polishing as received as femoral stem; (b) Ti-6Al7Nb after polishing; (c) Ti-6Al-4V after polishing.

Table 3. Surfaces statistics of Ti alloys as received (stem femoral) and after polishing.

\begin{tabular}{cccc}
\hline & $\begin{array}{c}\text { Ti-6Al-7N as } \\
\text { received }\end{array}$ & $\begin{array}{c}\text { Ti-6Al-7Nb after } \\
\text { preparation }\end{array}$ & $\begin{array}{c}\text { Ti-6Al-4V after } \\
\text { preparation }\end{array}$ \\
\hline $\operatorname{Ra}(\mu \mathrm{m})$ & 5.03 & 0.01 & 0.06 \\
$\operatorname{Rq}(\mu \mathrm{m})$ & 7.42 & 0.02 & 0.08 \\
$\operatorname{Rz}(\mu \mathrm{m})$ & 45.20 & 0.57 & 1.0 .5 \\
$\operatorname{Rt}(\mu \mathrm{m})$ & 40.43 & 0.54 & 1.19 \\
\hline
\end{tabular}

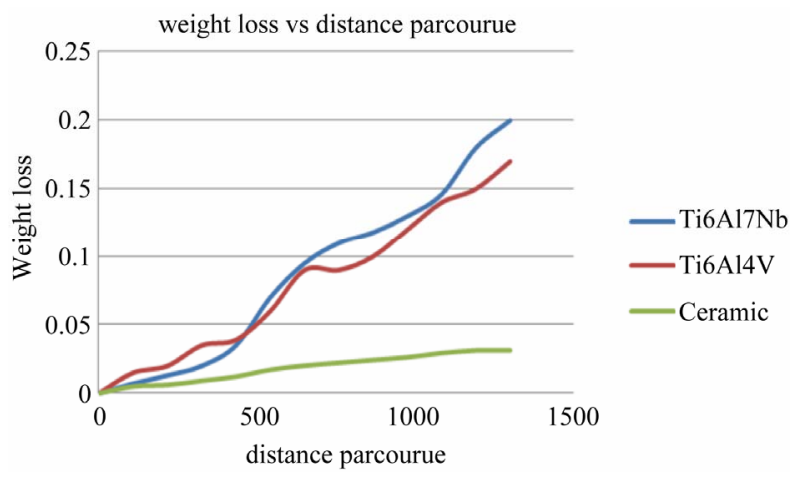

Figure 9. Wear diagrams (weight loss $\left(\mathrm{g} \cdot \mathrm{cm}^{-3}\right)$ ) of Ti-6Al$7 \mathrm{Nb}$, Ti-6Al-4V and ceramic sliding against (abrasive paper number 320).

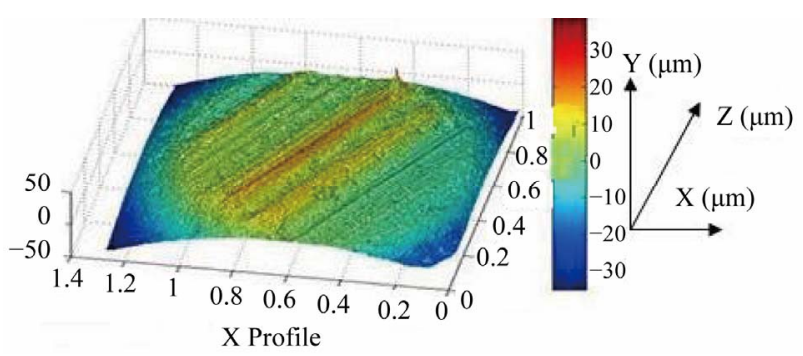

Figure 10. Wear marks of $100 \mathrm{C} 6$ steel ball under the following conditions: time $=1 \mathrm{~h}, \mathrm{FN}=10 \mathrm{~N}$, sliding speed 8 $\mathrm{mm} / \mathrm{s}$ with a same oscillating tribotester [31].

It is seen from Figure 11 that, the friction coefficient showed a lower value (approx. 0.248) up to 20 cycles and then it increased to the average 0.4 value between 40 and 1000 distance (cycles). The reason might be due to an oxide layer formed on Ti-6Al-7Nb and, therefore, the coefficient of friction showed the lower value until $20 \mathrm{~m}$. However, that oxide layer was torn and then 1006C ball was completely touched on the substrate and, therefore, the friction coefficient was obtained at a higher value (0.538). In Figure 12, it is seen that the friction coefficient curves of Ti-6Al-7Nb, are the same form for all test conditions sliding speed and normal load applied, the average friction coefficient was obtained as 0.54 at sliding speed $25 \mathrm{~mm} \cdot \mathrm{s}^{-1}$ under $10 \mathrm{~N}$, It is also obvious in Figure 12, that the coefficient of friction displayed a lower value of 0.129 up to 20 cycle at sliding speed 1 $\mathrm{mm} \cdot \mathrm{s}^{-1}$, under $3 \mathrm{~N}$ of normal load and then it sharply.

Increased to the average value of 0.518 (Table 4) for the same conditions $1 \mathrm{~mm} \cdot \mathrm{s}^{-1}$.

\section{1) Influence of the Load Applied to the Friction}

\section{Coefficient}

The influence of normal load applied on the evolution of friction coefficient of Ti-6Al-7Nb and Ti-6Al-4V under different condition of loads $(3,6$ and $10 \mathrm{~N})$ at sliding speeds $\left(1,15\right.$ and $\left.25 \mathrm{~mm} \cdot \mathrm{s}^{-1}\right)$, was represented in Table 5 and Figures 13-15. It is seen in the Figure 13, that the mean coefficient of friction at $1 \mathrm{~mm} \cdot \mathrm{s}^{-1}$ it 
Table 4. Values of friction coefficient of Ti-6Al-7Nb versus sliding distance $\left(1,15\right.$ and $\left.25 \mathrm{~mm} \cdot \mathrm{s}^{-1}\right)$ under different loads 3,6 and $10 \mathrm{~N}$.

\begin{tabular}{|c|c|c|c|c|c|c|c|c|c|c|c|c|c|c|c|}
\hline \multirow[b]{2}{*}{$\mathrm{FN}(\mathrm{N})$} & \multicolumn{5}{|c|}{$1 \mathrm{~mm} \cdot \mathrm{s}^{-1}$} & \multicolumn{5}{|c|}{$15 \mathrm{~mm} \cdot \mathrm{s}^{-1}$} & \multicolumn{5}{|c|}{$25 \mathrm{~mm} \cdot \mathrm{s}^{-1}$} \\
\hline & $\begin{array}{l}\text { Star } \\
\text { COF }\end{array}$ & $\begin{array}{l}\text { Min } \\
\text { COF }\end{array}$ & $\begin{array}{l}\text { Max } \\
\text { COF }\end{array}$ & $\begin{array}{l}\text { Mean } \\
\text { COF }\end{array}$ & $\begin{array}{l}\mathrm{PH} \mathrm{Ca} \\
(\mathrm{Mpa})\end{array}$ & $\begin{array}{l}\text { Star } \\
\text { COF }\end{array}$ & $\begin{array}{l}\text { Min } \\
\text { COF }\end{array}$ & $\begin{array}{l}\text { Max } \\
\text { COF }\end{array}$ & $\begin{array}{l}\text { Mean } \\
\text { COF }\end{array}$ & $\begin{array}{c}\mathrm{PH} \mathrm{Ca} \\
\text { (Mpa) }\end{array}$ & $\begin{array}{l}\text { Star } \\
\text { COF }\end{array}$ & $\begin{array}{l}\text { Min } \\
\text { COf }\end{array}$ & $\begin{array}{l}\text { Max } \\
\text { COF }\end{array}$ & $\begin{array}{l}\text { Mean } \\
\text { COF }\end{array}$ & $\begin{array}{l}\mathrm{PHCa} \\
\text { (Mpa) }\end{array}$ \\
\hline $3 \mathrm{~N}$ & 0.129 & 0.068 & 0.589 & 0.339 & 524 & 0.248 & 0.248 & 0.538 & 0.4 & 531 & 0.349 & 0.349 & 0.49 & 0.419 & 532 \\
\hline $6 \mathrm{~N}$ & 0.325 & 0.197 & 0.546 & 0.36 & 660 & 0.405 & 0.339 & 0.508 & 0.413 & 670 & 0.333 & 0.333 & 0.482 & 0.418 & 670 \\
\hline $10 \mathrm{~N}$ & 0.251 & 0.213 & 0.518 & 0.357 & 783 & 0.397 & 0.325 & 0.48 & 0.398 & 795 & 0.367 & 0.344 & 0.54 & 0.407 & 795 \\
\hline
\end{tabular}

PH Ca: Hertz pressure (calculated) (Mpa); Star COF: the start value of coefficient of friction; Min COF: the minimum value of coefficient of friction; Mean COF: the mean value of coefficient of friction; Max COF: the maximum value of coefficient of friction; FN (N): a normal load applied (N).

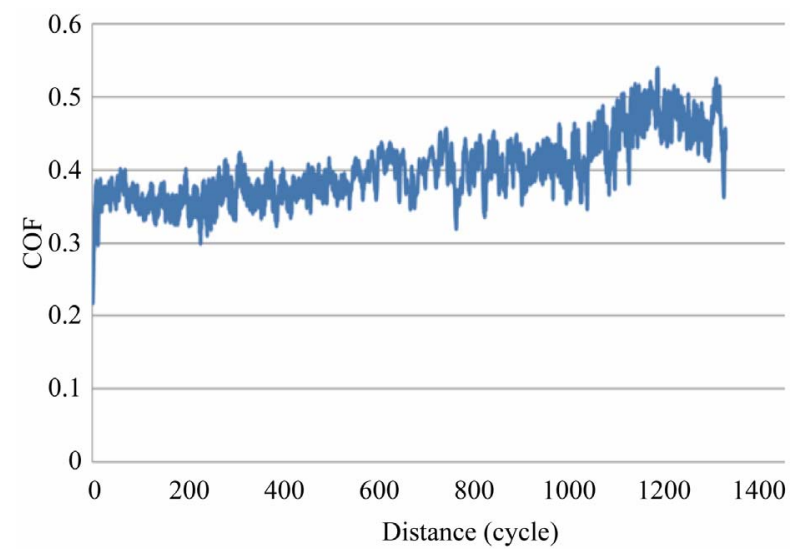

Figure 11. Friction coefficient vs. sliding distance for Ti6Al-7Nb under $3 \mathrm{~N}$ applied load at $15 \mathrm{~mm} \cdot \mathrm{s}^{-1}$ sliding speed.

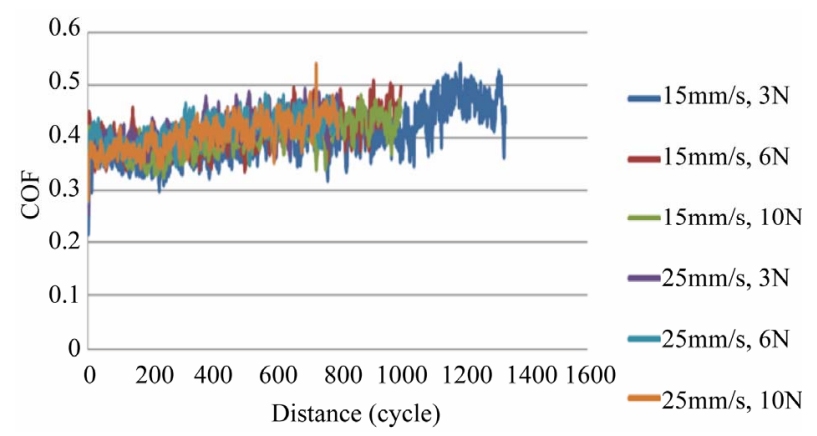

Figure 12. Friction coefficient vs. sliding distance for Ti6Al-7Nb under different conditions of load 3, 6 and $10 \mathrm{~N}$ at tows sliding speed 15 and $25 \mathrm{~mm} \cdot \mathrm{s}^{-1}$.

reaches the mean value of $0.339,0.36$ and 0.357 of Ti-6Al-7Nb under normal load 3, 6 and $10 \mathrm{~N}$ respectively, also it seen in the some Figure 13, that the Ti$6 \mathrm{Al}-4 \mathrm{~V}$ almost has the same mean value of friction coefficient of Ti-6Al-7Nb.

The Figures $\mathbf{1 4}$ and $\mathbf{1 5}$ are presented the evolution of friction coefficient of Ti-6Al-7Nb and Ti-6Al-4V vs. sliding distance under different conditions of load 3, 6 and $10 \mathrm{~N}$ at sliding speeds 1 and $25 \mathrm{~mm} \cdot \mathrm{s}^{-1}$ respectively, it seen that the samples almost has the same mean value of friction coefficient that's increased to the average values of $(0.37$ to 0.5$)$.

\section{2) Influence of Speed}

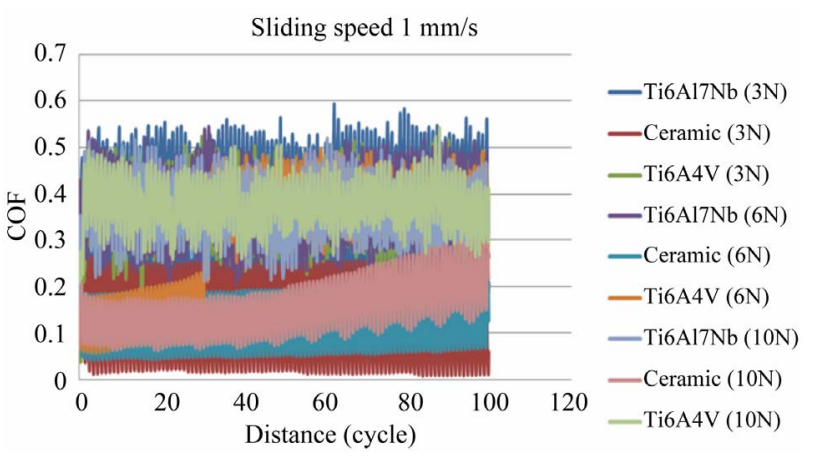

Figure 13. Friction coefficient vs sliding distance for $\mathrm{Ti}$ alloys and ceramic under different conditions of load 3, 6 and $10 \mathrm{~N}$ at $1 \mathrm{~mm} \cdot \mathrm{s}^{-1}$ sliding speed.

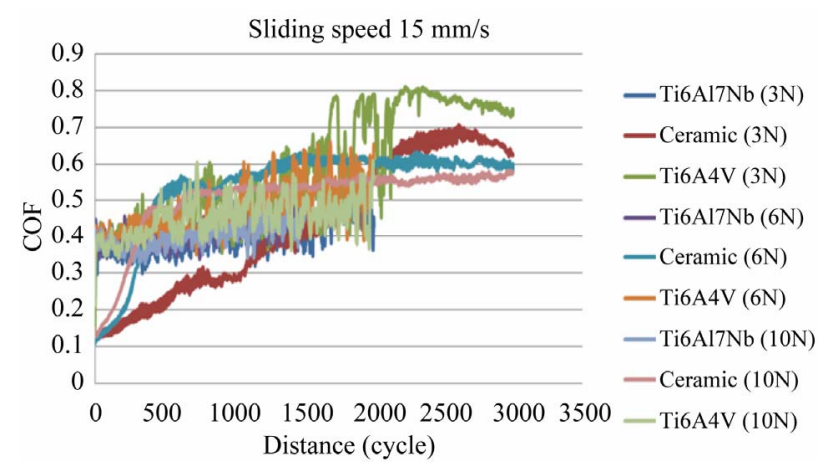

Figure 14. Friction coefficient vs sliding distance for Ti alloys and ceramic under different conditions of load 3, 6 and $10 \mathrm{~N}$ at $15 \mathrm{~mm} \cdot \mathrm{s}^{-1}$ sliding speed.

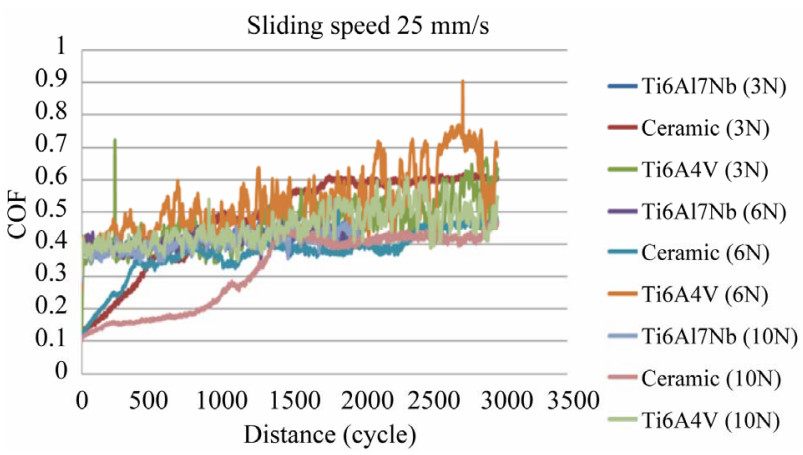

Figure 15. Friction coefficient vs sliding distance for $\mathrm{Ti}$ alloys and ceramic under different conditions of load 3, 6 and $10 \mathrm{~N}$ at $25 \mathrm{~mm} \cdot \mathrm{s}^{-1}$ sliding speed. 


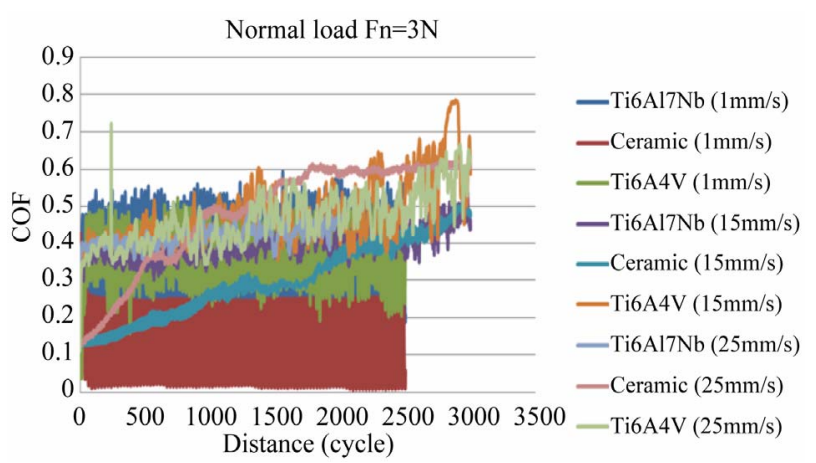

Figure 16. friction coefficient vs sliding distance for $\mathrm{Ti}$ alloys and ceramic under different conditions of sliding speed 1, 15 and $25 \mathrm{~mm} \cdot \mathrm{s}^{-1}$ at normal load $3 \mathrm{~N}$.

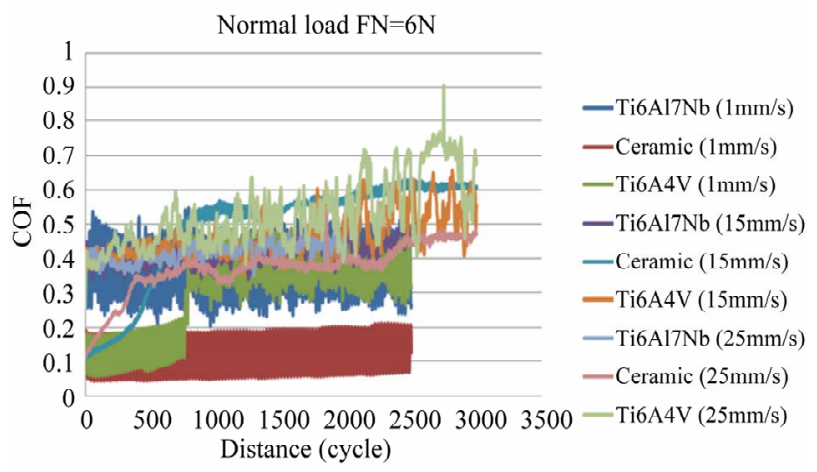

Figure 17. Friction coefficient vs sliding distance for $\mathbf{T i}$ alloys and ceramic under different conditions of sliding speed 1,15 and $25 \mathrm{~mm} \cdot \mathrm{s}^{-1}$ at normal load $6 \mathrm{~N}$.

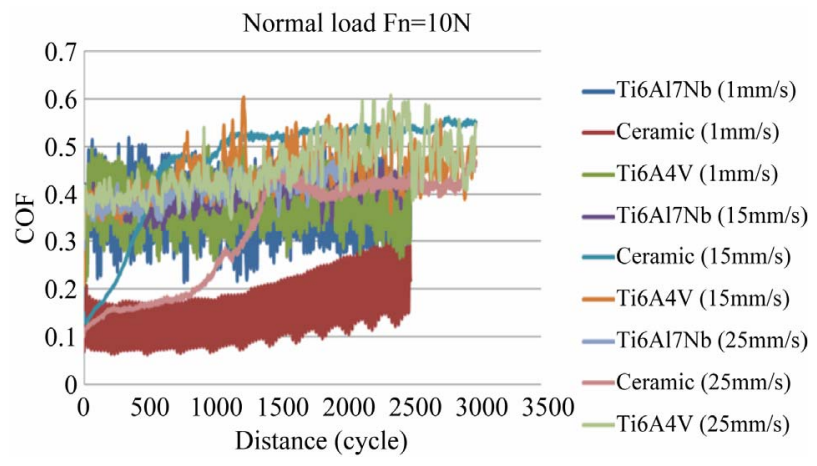

Figure 18. Friction coefficient vs sliding distance for $\mathrm{Ti}$ alloys and ceramic under different conditions of sliding speed 1,15 and $25 \mathrm{~mm} \cdot \mathrm{s}^{-1}$ at normal load $10 \mathrm{~N}$.

Figures 16-18, represented the influence of loads applied to the evolution of friction coefficient of Ti-6Al$7 \mathrm{Nb}$, and Ti-6Al-4V under different condition sliding speeds $\left(1,15\right.$ and $\left.25 \mathrm{~mm} \cdot \mathrm{s}^{-1}\right)$, at 3, 6 and $10 \mathrm{~N}$ load applied respectively. It is seen that the mean coefficient of friction of the samples displayed a lower value at 1 $\mathrm{mm} \cdot \mathrm{s}^{-1}$ sliding speed, and then it sharply increased to the average value with increasing of sliding speed as showing in the Table 5 and Figure 19.

\subsubsection{Wear}

In the wear test, the volumetric wear rate was calculated by the help of mechanical profilometer as $57.62 \times 10^{-3}$ $\mathrm{mm}^{3} \cdot \mathrm{N} \cdot \mathrm{mm}^{-1}$ for the Ti-6Al-Nb. A 100C6 ball did the grinding from the sample surface, that is, abrasive wear occurred on the surface and this is illustrated in Figures 20 and 21. Volumetric wear was determined as $5.48 \times$ $10^{-3}, 9.64 \times 10^{-3}$ and $13.12 \times 10^{-3} \mathrm{~mm}^{3} \cdot \mathrm{N} \cdot \mathrm{mm}^{-1}$ at 1 $\mathrm{mm} \cdot \mathrm{s}^{-1}$ sliding speed under loads 3,6 and 10 respectively. Finally, the volumetric wear was a same for a both sliding speed 15 and 25 between $20.67 \times 10^{-3} \mathrm{~mm}^{3} \cdot \mathrm{N} \cdot \mathrm{mm}^{-1}$ and $57.62 \times 10^{-3} \mathrm{~mm}^{3} \cdot \mathrm{N} \cdot \mathrm{mm}^{-1}$. Table 6 and Figure 19, provides the wear volume of the investigated alloys as a function of the sliding speed. The volumetric wear data reveal that the volume loss, irrespective of alloy composition and microstructure, increases as the sliding speed increases.

Friction versus wear: The strength of materials depends on three groups of factors in friction conditions [35]. Those factors are shown as follows:

1) Internal reasons determined material property;

2) Friction type (slipping, rolling) and working conditions (relative movement speed, load, application type, temperature); and

3) Working environment and lubricants.

\section{Conclusions}

Wear characteristics of high-strength titanium alloys Ti-6Al-7Nb were evaluated in a wear test simulating the friction for Total hip prosthesis application. The oscillating friction and wear resistance have been carried out in ambient air with oscillating tribotester in accord with standards ISO 7148, ASTM G99-95a and ASTM G13395. On the one hand, the friction and wear tests were carried out to see the type of wear and to quantify the weight loss; on the other hand, to see the variation in the friction coefficient of the studied couples under different conditions of load (3, 6 and $10 \mathrm{~N})$ and sliding speed (1, 15 and $25 \mathrm{~mm} \cdot \mathrm{s}^{-1}$ ) as counter pairs, we used the ball of $100 \mathrm{C} 6 \mathrm{steel}, 10 \mathrm{~mm}$ in diameter. The following observations and conclusions were obtained:

1) The wear resistance of Ti-6Al-7NB alloy is substantially lower than that of the Ti-6Al-4V tested under deferent conditions of load and sliding speed. The extent of wear is smallest for Ti-6Al-4V with highest hardness.

2) The coefficient friction as shown in Figure 19, of both alloys increases with increasing sliding speed. However, Ti-6Al-7 $\mathrm{Nb}$ alloy shows no significant variation of coefficient of friction with (15 and $\left.25 \mathrm{~mm} \cdot \mathrm{s}^{-1}\right)$ sliding speeds, while the coefficient of Ti-6Al-4V increases linearly with increasing sliding speed. This behavior is attributed to the predominant wear mechanism.

3) The two Ti alloys had similar friction and wear performance, although their grain structures and composi- 
Table 5. Mean value of coefficient of friction of Ti alloys and ceramic under different conditions of sliding speeds (1, 15 and $\left.25 \mathrm{~mm} \cdot \mathrm{s}^{-1}\right)$ and normal loads $(3,6$ and $10 \mathrm{~N})$.

\begin{tabular}{|c|c|c|c|c|c|c|}
\hline \multirow{2}{*}{$\frac{\text { Speed }}{\text { Fn }(N)}$} & \multicolumn{2}{|c|}{$1 \mathrm{~mm} \cdot \mathrm{s}^{-1}$} & \multicolumn{2}{|c|}{$15 \mathrm{~mm} \cdot \mathrm{s}^{-1}$} & \multicolumn{2}{|c|}{$25 \mathrm{~mm} \cdot \mathrm{s}^{-1}$} \\
\hline & Ti-6Al-7Nb & Ti-6Al-4V & Ti-6Al-7Nb & Ti-6Al-4V & Ti-6Al-7Nb & Ti-6Al-4V \\
\hline $6(\mathrm{~N})$ & 0.36 & 0.297 & 0.413 & 0.473 & 0.418 & 0.565 \\
\hline $10(\mathrm{~N})$ & 0.357 & 0.374 & 0.398 & 0.452 & 0.407 & 0.476 \\
\hline
\end{tabular}

Table 6. Volumetric wear rate of Ti-6Al-7Nb and Ti-6Al-4V under different conditions of sliding speeds $(1,15$ and 25 $\mathrm{mm} \cdot \mathrm{s}^{-1}$ ) and normal loads $(3,6$ and10 $\mathrm{N})$.

\begin{tabular}{cccc}
\hline $\begin{array}{c}\text { Sliding speed } \\
\mathrm{mm} / \mathrm{s}\end{array}$ & Load $(\mathrm{N})$ & \multicolumn{2}{c}{ Volumetric wear $\mathrm{mm}^{3} \cdot \mathrm{N} \cdot \mathrm{mm}^{-1}$} \\
\cline { 2 - 4 } & 3 & Ti-6Al-4V & Ti-6Al-7Nb \\
\hline $1 \mathrm{~mm} \cdot \mathrm{s}^{-1}$ & 6 & $8.24 \times 10^{-3}$ & $5.48 \times 10^{-3}$ \\
& 10 & $11.08 \times 10^{-3}$ & $9.64 \times 10^{-3}$ \\
& 3 & $20.35 \times 10^{-3}$ & $22.06 \times 10^{-3}$ \\
$15 \mathrm{~mm} \cdot \mathrm{s}^{-1}$ & 6 & $37.98 \times 10^{-3}$ & $38.1 \times 10^{-3}$ \\
& 10 & $51.55 \times 10^{-3}$ & $57.35 \times 10^{-3}$ \\
& 3 & $27.32 \times 10^{-3}$ & $31.38 \times 10^{-3}$ \\
$25 \mathrm{~mm} \cdot \mathrm{s}^{-1}$ & 6 & $42.15 \times 10^{-3}$ & $45.28 \times 10^{-3}$ \\
& 10 & $54.21 \times 10^{-3}$ & $57.62 \times 10^{-3}$ \\
\hline
\end{tabular}

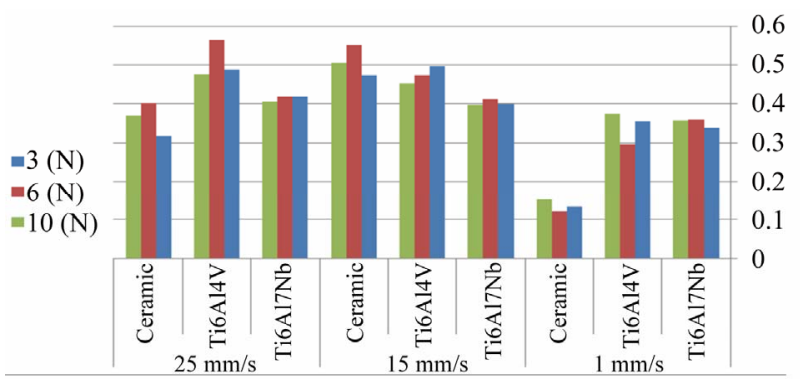

Figure 19. Mean coefficient of friction of Ti alloys and ceramic under different conditions of sliding speeds (1, 15 and $\left.25 \mathrm{~mm} \cdot \mathrm{s}^{-1}\right)$ and applied loads $(3,6$ and $10 \mathrm{~N})$.

tions are different.

4) Large frictional fluctuations occurred, probably caused by formation and periodic, localized fracture of a transfer layer.

5) Higher friction coefficient with larger fluctuation and higher wear rate were observed at the higher siding speed.

6) In all curves under deferent conditions, the friction coefficient firstly decreases and then increases as a function of the sliding distance. The evolution of the friction coefficient is related to composition of the worn surfaces.

7) The wear mechanism of Ti-6Al-4V transforms from ploughing and peeling off wear at low sliding speed to
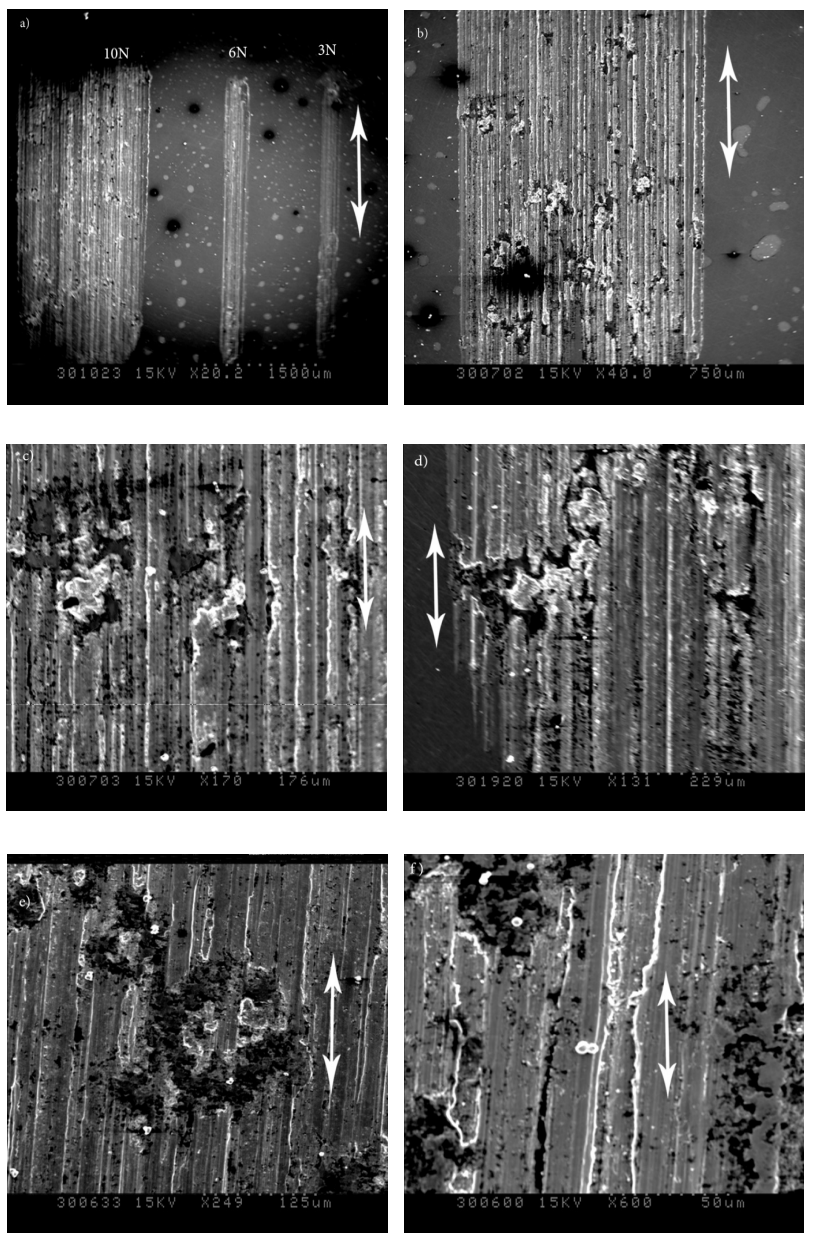

Figure 20. The worn surfaces, severe deformation and plastic flow of Ti-6Al-4V, sliding against ball $100 \mathrm{C} 6$ steel $(r=10$ mm): (a) Wear marks under normal load 3, 6 and $10 \mathrm{~N}$ at sliding speed $15 \mathrm{~mm} \cdot \mathrm{s}^{-1}$; (b) and (c) At normal load $6 \mathrm{~N}$ and sliding speed $15 \mathrm{~mm} \cdot \mathrm{s}^{-1}$; (d) and (e) At normal load $10 \mathrm{~N}$ and sliding speed $15 \mathrm{~mm} \cdot \mathrm{s}^{-1}$; (f) At normal load $10 \mathrm{~N}$ and sliding speed $25 \mathrm{~mm} \cdot \mathrm{s}^{-1}$. Arrows indicate the sliding direction.

plastic deformation and adhesive wear at elevated speed.

8) The weight loss quantifying the wear of a soft body slipping on a hard surface is proportional not only to the distance from the slip but also with the normal load applied.

9) The sliding speed has a principal effect to act on the temperature of the contact zone. Going beyond a critical 

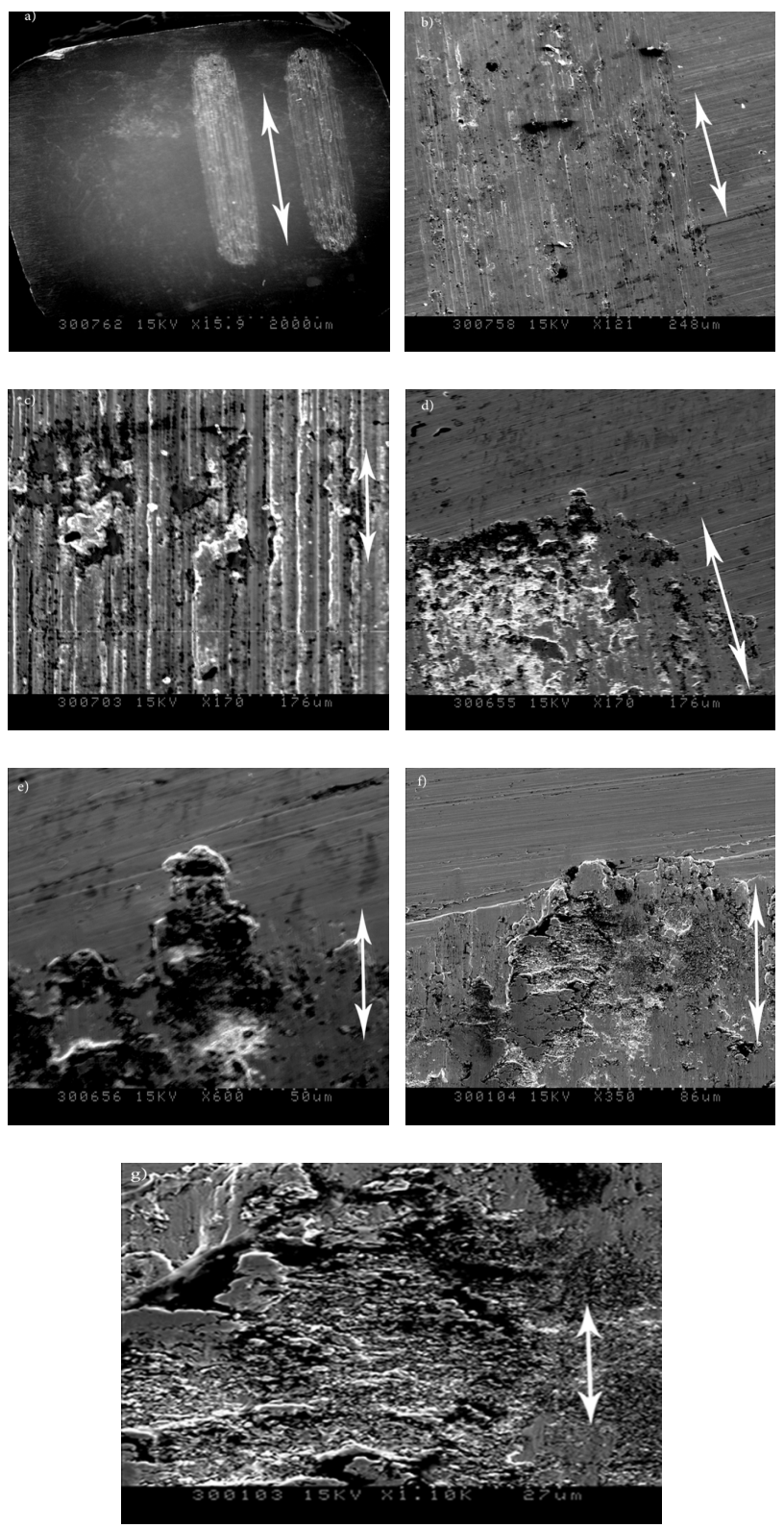

Figure 21. The worn surfaces, severe deformation and plastic flow of Ti-6Al-7Nb sliding against ball $1006 \mathrm{C6}$ steel $(r=$ $10 \mathrm{~mm}$ ), under normal load $6 \mathrm{~N}$ at sliding speed $15 \mathrm{~mm} \cdot \mathrm{s}^{-1}$ ((a), (b) and (c)), normal load $10 \mathrm{~N}$ at sliding speed 15 $\mathrm{mm} \cdot \mathrm{s}^{-1}((\mathrm{~d})$ and (e)), and normal load normal load $10 \mathrm{~N}$ at sliding speed $25 \mathrm{~mm} \cdot \mathrm{s}^{-1}$ ((f) and (g)). Arrows indicate the sliding direction.

speed involves the surface fusion of the most fusible body.

10) The increase in the temperature of the contact with the speed inducing structure transformations increases the reactivity of surfaces with respect to the environment (oxidation in the presence of air). Above a certain temperature and thus for speeds of slip higher than a breaking value, the oxide film, resulting from a permanent oxidation, is reconstituted with the fur as it is destroyed by wear.

\section{Acknowledgements}

This work was realized in collaboration with the metallurgical laboratory of ARTS ET METIERS ParisTech in Lille, France. The authors wish to thank Prof. Alain Iost the Director of Laboratory of Metallurgy, for kindly supplying the Ti-6Al-4V metal bars and Ti-6Al-7Nb femoral stem, and permitting facilities to use the SEM and tribotester.

\section{REFERENCES}

[1] M. Niinomi, "Mechanical Biocompatibilities of Titanium Alloys for Biomedical Application," Journal of the Mechanical Behavior of Biomedical Materials, Vol. 1, No. 1, 2008, pp. 30-42.

http://dx.doi.org/10.1016/j.jmbbm.2007.07.001

[2] L. E. Murr, S. A. Quinones, S. M. Gaytan, M. I. Lopez, A. Rodela, et al., "Microstructure and Mechanical Behaviour of Ti-6Al-4V Produced by Rapid-Layer Manufacturing, for Biomedical Applications," Journal of the Mechanical Behavior of Biomedical Materials, Vol. 2, No. 1, 2009, pp. 20-32. http://dx.doi.org/10.1016/j.jmbbm.2008.05.004

[3] Z.-B. Caia, G.-A. Zhangb, Y.-K. Zhua, et al., "Torsional Fretting Wear of a Biomedical Ti6Al7Nb Alloy for Nitrogen Ion Implantation in Bovine Serum," Tribology International, Vol. 59, 2013, pp. 312-320. http://dx.doi.org/10.1016/j.triboint.2012.06.009

[4] N. Masahashi, Y. Mizukoshi, S. Semboshi, K. Ohmura, S. Hanada, et al., "Photo-Induced Properties of Anodicoxidelms on Ti6Al4V," Journal of Thin Solid Films, Vol. 520, No. 15, 2012, pp. 4956-4964. http://dx.doi.org/10.1016/j.tsf.2012.03.026

[5] M. Janecek, F. Nový, J. Stráský, P. Harcuba and L. Wagner, "Fatigue Endurance of Ti-6Al-4V Alloy with Electro-Eroded Surface for Improved Bone In-Growth," Journal of the Mechanical Behavior of Biomedical Materials, Vol. 4, No. 3, 2011, pp. 417-422.

http://dx.doi.org/10.1016/j.jmbbm.2010.12.001

[6] J. Chenga, J. Yanga, X. Zhang, H. Zhong, J. Ma, et al., "High Temperature Tribological Behaviour of a Ti-46Al2Cr-2Nb Intermetallics," Intermetallics, Vol. 31, 2012, pp. 120-126. http://dx.doi.org/10.1016/j.intermet.2012.06.013

[7] L. Bolzoni, E. M. Ruiz Navas, E. Neubauer and E. Gordo, "Mechanical Properties and Micro Structural Evolution of Vacuum Hot-Pressed Titanium and Ti-6Al-7Nb Alloy," Journal of the Mechanical Behaviour of Biomedical Materials, Vol. 9, 2012, pp. 91-99. http://dx.doi.org/10.1016/j.jmbbm.2012.01.015

[8] K. Ida, Y. Tani, S. Tsutsumi, T. Togaya, T. Nambu, et al., "Clinical Application of Pure Titanium Crowns," Journal of Dental Materials, Vol. 4, No. 2, 1985, pp. 191-195. http://dx.doi.org/10.4012/dmj.4.191

[9] B. Bergman, C. Bessing, G. Ericson, P. Lundquist, H. Nilson, et al., "A 2-Year Follow-Up Study of Titanium Crowns," Acta Odontologica Scandinavica, Vol. 48, No. 


\section{2, 2011, pp. 113-117.}

[10] T. Hirata, T. Nakamura, F. Takashima, T. Maruyama, M. Taira, et al., "Studies on Polishing of Ag-Pd-Cu-Au Alloy with Five Dental Abrasives," Journal of Oral Rehabilitation, Vol. 28, No. 8, 2011, pp. 773-777. http://dx.doi.org/10.1046/j.1365-2842.2001.00737.x

[11] T. Kawazoe and K. Suese, "Clinical Application of Titanium Crowns," Dental Materials Journal, Vol. 30, No. 3, 1989, pp. 317-328.

[12] A. Kuroiwa and Y. Igarashi, "Application of Pure Titanium to Metal Framework," Nihon Hotetsu Shika Gakkai Zasshi, Vol. 42, No. 4, 1998, pp. 547-558. http://dx.doi.org/10.2186/jips.42.547

[13] M. A. Khan, R. L. Williams and D. F. Williams, "In-Vitro Corrosion and Wear of Titanium Alloys in the Biological Environment," Biomaterials, Vol. 17, No. 22, 1996, pp. 2117-2126. http://dx.doi.org/10.1016/0142-9612(96)00029-4

[14] S. Tamilselvi, R. Murugaraj and N. Rajendran, "Electrochemical Impedance Spectroscopic Studies of Titanium and Its Alloys in Saline Medium," Material and Corrosion, Vol. 58, No. 2, 2007, pp. 113-119. http://dx.doi.org/10.1002/maco.200603979

[15] S. Tamilselvi and N. Rajendran, "In Vitro Corrosion Behavior of Ti-5Al-2Nb-1Ta Alloy in Hanks Solution," Materials and Corrosion, Vol. 58, No. 4, 2007, pp. 285289. http://dx.doi.org/10.1002/maco.200604001

[16] A. Guitar, G. Vigna and M. I. Luppo, "Microstructure and Tensile Properties after Thermo Hydrogen Processing of Ti-6Al-4V," Journal of Mechanical Behavior of Biomedical Materials, Vol. 2, No. 2, 2009, pp. 156-163. http://dx.doi.org/10.1016/j.jmbbm.2008.06.002

[17] C. R. Ramos-Saenz, F. A. Sundaram and N. DiffootCarlo, "Tribological Properties of Ti-Based Alloys in Simulated Bone Implant Interface with Ringer's Solution at Fretting Contacts," Journal of Mechanical Behavior of Biomedical Materials, Vol. 3, No. 8, 2010, pp. 549-558. http://dx.doi.org/10.1016/j.jmbbm.2010.06.006

[18] R. C. Browne, "Vanadium Poisoning from Gas Turbines," British Journal of Industrial Medicine, Vol. 2, No. 12, 1955, pp. 57-59.

[19] S.-G. Sjöberg, "Vanadium Dust, Chronic Bronchitis and Possible Risk of Emphysema: A Follow-Up Investigation of Workers at a Vanadium Factory," Journal of Internal Medicine, Vol. 154, No. 5, 1956, pp. 381-386.

[20] P. G. Laing, "Clinical Experience with Prosthetic Materials: Historical Perspectives, Current Problems and Future Directions. Corrosion and Degradation of Implant Materials," ASTM-STP 684, B. C. Syrett and A. Acharya, Eds., American Society for Testing and Materials, 1979, pp. 199-211.

[21] M. Geetha, A. K. Singh, R. Asokamini and A. K. Gogia, "Ti Based Biomaterials, the Ultimate Choice for Orthopaedic Implants-A Review," Progress in Materials Science, Vol. 54, No. 3, 2009, pp. 397-425. http://dx.doi.org/10.1016/j.pmatsci.2008.06.004

[22] G. B. Van der Volt, E. Marani, S. Tio and F. A. De Wolff, "Aluminum Neurotoxicity," In: W. Graumann and J.
Drukker, Eds., "Histo- and Cyto-Chemistry as a Tool in Environmental," Toxicology, Fisher, Stuttgart, Germany, 1991, pp. 235-242.

[23] D. R. C. McLachlan, G. Farnees and I. T. Galin, "Biological Aspects of Metals and Metal Related Diseases," Ravan Press, New York, 1983.

[24] D. Scharnweber, "Degradation (in Vitro-in Vivo Corrosion)," In: J. A. Helsen and H. Jürgen Breme, Eds., Metals as Biomaterials, John Willey \& Sons, London, 1998, pp. 101-151.

[25] M. F. Lopez, L. Soriano, F. J. Palomares, M. SanchezAgudo, G. G. Fuentes, et al., "Soft X-Ray Absorption Spectroscopy Study of Passive and Oxide Layers of Titanium Alloys," Surface and Interface Analysis, Vol. 33, No. 7, 2002, pp. 570-579.

http://dx.doi.org/10.1002/sia.1422

[26] C. Morand, M. F. Lopez, A. Gutierrez and J. A. Jimenez, "AFM and SEM Characterization of Non-Toxic Vanadium-Free Ti Alloys Used as Biomaterials," Applied Surface Science, Vol. 220, No. 1-4, 2003, pp. 79-87. http://dx.doi.org/10.1016/S0169-4332(03)00746-3

[27] M. F. Lopez, J. A. Jimenez and A. Gutierrez, "Corrosion Study of Surface-Modified Vanadium-Free Titanium Alloys," Electrochimica Acta, Vol. 48, No. 10, 2003, pp. 1395-1401. http://dx.doi.org/10.1016/S0013-4686(03)00006-9

[28] M. F. Semlitsch, H. Weber and R. M. Streicher, "Joint Replacement Components Made of Hot-Forged and Surface-Treated Ti-6Al-7Nb Alloy," Biomaterials, Vol. 13, No. 11, 1992, pp. 781-888. http://dx.doi.org/10.1016/0142-9612(92)90018-J

[29] E. Kobayashi, T. J. Wang, H. Doi, T. Yoneyama and H. Hamanaka, "Mechanical Properties and Corrosion Resistance of Ti-6Al-7Nb Alloy Dental Castings," Journal of Materials Science: Materials in Medicine, Vol. 9, No. 10, 1998, pp. 567-574. http://dx.doi.org/10.1023/A:1008909408948

[30] E. Confortoa, B.-O. Aronssonb, A. Salitoc, C. Crestoud and D. Caillard, "Rough Surfaces of Titanium and Titanium Alloys for Implants and Prostheses," Materials Science and Engineering C: Biomimetic and Supramolecular systems, Vol. 24, No. 5, 2004, pp. 611-618.

[31] Brahim TLILI, "Caractérisation de Films durs Multicouches Elaborés par Pulvérisation Magnétron. Influence des Conditions d'Élaboration sur Leurs Propriété," Le 9 Décembre 2010 École Doctorale No. 432: Sciences des Métiers de l'Ingénieur Doctorat ParisTech Pastel-00573968, Version 1-6, 2011.

[32] Norme Internationale (F) Implants Chirurgicaux-Prothèses Partielles et Totales de l'Articulation de la Hanche-Partie 2, ISO 7206-2, Surfaces Articulaires Constituées de Matériaux Métalliques, Céramiques et Plastiques, 1996.

[33] J. F. Archard, "Contact and Rubbing of Flat Surfaces," Journal of Applied Physics, Vol. 24, No. 8, 1953, pp. 981-988. http://dx.doi.org/10.1063/1.1721448

[34] L. Avril, "Elaboration de Revêtements sur Acier Inoxydable Simulation de la Fusion par Irradiation Laser Carac- 
térisation Structurale, Mécanique et Tribologique," Thèse, Ecole Nationale Superieure (432), n d'ordre 2003-16.

[35] H. Paetzold and E. Ilinich, "Determination of the Dy- namic Friction Coefficient of Cartilage with Different Biomaterials," Journal of Biomechanics, Vol. 41, No. S1, 2008. 